\title{
Total Phenolic Compounds and Antioxidant Activity of Organic Vegetables Consumed in Brazil
}

\author{
Verona Borges Ferreira, Thadia Turon Costa da Silva*, Silvia Regina Magalhães Couto, \\ Armando Ubirajara Oliveira Sabaa Srur \\ Centro de Ciências da Saúde, Instituto de Nutrição Josué de Castro, Universidade Federal do Rio de Janeiro, \\ Rio de Janeiro, Brasil \\ Email: thadia@uol.com.br
}

Received 3 November 2014; accepted 14 June 2015; published 17 June 2015

Copyright (C) 2015 by authors and Scientific Research Publishing Inc.

This work is licensed under the Creative Commons Attribution International License (CC BY). http://creativecommons.org/licenses/by/4.0/

c) (i) Open Access

\begin{abstract}
Organic olericulture differs from conventional agriculture due to the absence of pesticide, synthetic fertilizers, genetically modified organisms, some food additives and ionizing radiation, producing vegetables with a different chemical composition and with different amounts of bioactive compounds. The objective of this study was to quantify, in organic vegetables consumed in Brazil, the amount of total phenolic compounds using Folin-Ciocalteu reagent and the antioxidant activity through DPPH method. Among the analyzed vegetables, the effectiveness in the antioxidant capacity was obtained in decreasing order, by the broccoli (69.35), kale (63.20), cabbage (35.72) and carrot (20.39), expressed in \% of DPPH consumption after 30 minutes of reaction. The amount of total phenolic compounds ( $\mathrm{mg} \mathrm{GAE} / \mathrm{ml}$ of fluid extract-FE) present in the kale $(0.606)$, broccoli $(0.511)$, cabbage $(0.214)$ and carrots $(0.124)$ demonstrates a positive correlation between phenolic amounts and the antioxidant activity of the vegetables analyzed.
\end{abstract}

\section{Keywords}

Organic Food, Bioactive Compounds, Vegetables, Antioxidant, DPPH

\section{Introduction}

Food of plant origin, especially vegetables, is the source of vitamins, minerals, fibers, carbohydrates and bioactive compounds, such as polyphenols, a group of phytochemicals acknowledged as the most plentiful in our diet

\footnotetext{
"Corresponding author.
}

How to cite this paper: Ferreira, V.B., da Silva, T.T.C., Couto, S.R.M. and Srur, A.U.O.S. (2015) Total Phenolic Compounds and Antioxidant Activity of Organic Vegetables Consumed in Brazil. Food and Nutrition Sciences, 6, 798-804. 
[1]. The protection assigned to the antioxidants is derived from its reducing action towards reactive oxygen and nitrogen species, generated from endogenous or exogenous sources, such as tobacco, air pollution, organic solvents, anesthetics, pesticides and radiation. If in excessive amounts, these reactive substances may cause cellular damages and may also contribute to the emergence of chronic non-communicable diseases [2]-[6].

World Health Organization (WHO) asserts that, with scientific evidence level, an increase in fruits, vegetables and whole cereals intake has significant positive effects on the overall health of people, more specifically, on preventing non-communicable diseases [7]. However, Brazilian housing availability for fruits and vegetables has been estimated in $2.8 \%$ of the total calories, or one fourth of the recommended amounts. These numbers indicate that less than $10 \%$ of the Brazilian population reaches the recommended amounts for fruits and vegetables intake [8].

Organic vegetables production aims the encouragement of a rational use of the soil, water and air, reducing to minimum levels of the employment of non-renewable resources. Its purpose is to offer healthy food items, free from intentional contaminants that can generate risks for the environment or for the farmer's or consumer's health. It differs from the conventional agriculture for its non-usage of agrochemicals, synthetic fertilizers, genetically modified organisms, some food additives and ionizing radiation [9] [10]. The chemical composition and the amounts of bioactive compounds may vary due to environmental conditions and culture manipulation; therefore it becomes necessary to search for a characterization of the organic vegetables produced in Brazil [11]-[16]. Flavonoids (flavones and flavonols), phenolic acids, stilbenes and lignans that are found in vegetables in their free forms or bound to sugars (glycosides) or proteins are classified as phenolic compounds [17].

The objective of this study was to quantify, in organic vegetables consumed in Brazil, the amount of total phenolic compounds using Folin-Ciocalteu reagent and the antioxidant activity through DPPH method. The study presents the contents of phenolic compounds and the antioxidant capacity of organic carrot (Daucus carota L.), broccoli (Brassica oleracea var. Italica), kale (Brassica oleracea var. Acephala) and cabbage (Brassica oleracea var. Capitata) produced in Petropolis, a small mountainous city in the state of Rio de Janeiro-Brazil.

\section{Material and Methods}

The samples were randomly harvested in farms, from 2011 to 2013, in crop growing farms, at the beginning, center and end regions of the beds, totalizing five harvests and three batches for each vegetable in each harvest. The vegetables samples were transported in refrigerated vehicles $\left(5^{\circ} \mathrm{C}\right)$ to the laboratory where they went through a process of selection, hygienic cleaning, manual peeling and grinding in a food processor so they could be used in preparing the extracts.

\subsection{Antioxidant Activity through the DPPH Radical Scavenging Process}

The DPPH method is based on the capture of the purple colored DPPH radical (2,2-diphenyl-1-picrylhydrazyl), which absorbs at $517 \mathrm{~nm}$. By the action of an antioxidant or a radical species, the $\mathrm{DPPH}^{*}$ is reduced creating 2,2diphenyl-1-picrylhydrazyl, of a yellow color, and consequent absorption disappearance, so it can be monitored by the decrease of absorbance. Based on the results obtained it is possible to obtain the free radical antioxidant or scavenging activity percentage and/or the DPPH remaining percentage in the reaction environment [18]-[23].

The DPPH method was performed according to the process described by Rufino et al. [24], Sánchez-Moreno et al. [19] and Brand-Williams, et al. [18]. Extracts were prepared from fresh vegetables, using an $80 \%$ methanol hydroalcoholic solution at $70^{\circ} \mathrm{C}$ for 10 minutes. They were repeatedly homogenized and filtered, and later concentrated in a rotary evaporator at $40^{\circ} \mathrm{C}$ for 15 minutes. A quantity of $0.1 \mathrm{ml}$ of the sample was added to a $3.9 \mathrm{ml}$ DPPH (Sigma-Aldrich, Germany) radical solution at $100 \mu \mathrm{M}$, dissolved in methanol at $80 \%$. It was carefully homogenized and stored in the dark at room temperature $\left(25^{\circ} \mathrm{C} \pm 1{ }^{\circ} \mathrm{C}\right)$. The absorbance was measured using a Spectrophotometer Anthos Zenyth 200st equipment, at a $517 \mathrm{~nm}$ wave length $(\gamma)$ after 15, 30 and 60 minutes reaction time ( $\left.\mathbf{A b s}_{\text {sample }}\right)$. The tests were performed in triplicate and based on the data obtained the percentage of DPPH consumed was calculated, with the help of Equation (1):

$$
\% \mathrm{DPPH}_{\text {consumed }}=100-\left\{\left[\left(\mathrm{Abs}_{\text {sample }}-\mathrm{Abs}_{\text {white }}\right) \times 100\right] / \mathrm{Abs}_{\text {control }}\right\}
$$

\subsection{Content of Total Phenolic Compounds}

The phenolic compounds standard curve was constructed with gallic acid (Sigma-Aldrich, Germany). The stock 
solution was prepared with $100 \mathrm{mg}$ of gallic acid diluted with methanol at $80 \%$ in a $10 \mathrm{ml}$ volumetric flask. A 1 $\mathrm{ml}$ aliquot was removed from the stock solution and it was diluted with methanol at $80 \%$ in a 100 ml volumetric flask, establishing the sample solution. Aliquots of 0.05 at $1.2 \mu \mathrm{g} / \mathrm{ml}$ were removed from that sample solution and they were mixed with $1600 \mu \mathrm{L}$ to $2600 \mu \mathrm{L}$ Folin Ciocalteu reagent (Sigma-Aldrich, Germany) and with $1280 \mu \mathrm{L}$ of $\mathrm{Na}_{2} \mathrm{CO}_{3}$ at $20 \%$. The homogenization was carried on, leaving the solutions at rest at room temperature for 2 hours, and then the concentrations were measured. The results were expressed in $\mu \mathrm{g}$ of gallic acid $/ \mathrm{mL}$. All the analysis were performed in triplicates.

An amount of $20 \mathrm{~g}$ of each sample was diluted in methanol in a $100 \mathrm{ml}$ volumetric flask to obtain the vegetables extracts. The content was agitated for one hour, on a non-heated stirrer plate with the help of a bar magnet. Right after that it was vacuum filtered with a sintered funnel number 3, adapted according to the Swain and Hillis [25] and Torres et al. [26] methodology. Aiming the determination of the total amount of phenolic in the samples, $7 \mathrm{ml}$ of distilled water, $0.5 \mathrm{ml}$ of Folin-Ciocalteu reagent and $0.5 \mathrm{ml}$ of each extract were mixed. After 3 minutes, $2 \mathrm{ml}$ of $\mathrm{Na}_{2} \mathrm{CO}_{3}$ at $20 \%$ were added and heated at $100^{\circ} \mathrm{C}$ for one minute in a double boiler.

The absorbency was determined using a Spectrophotometer Model Nova 2000 UV equipment, with a 685 nm wave length $(\gamma)$, after being cooled at the absence of light [27] [28]. The total amount of phenolic was determined by the samples' absorbency interpolation with the calibration curve constructed with gallic acid patterns $(0.10$ at $0.22 \mu \mathrm{g} / \mathrm{ml}$ ) and expressed as mg of GAE (gallic acid equivalent) per ml of fluid extract. The gallic acid calibration curve equation was $\mathrm{Y}=2.416 \mathrm{x}-0.002$ and the correlation coefficient was $\mathrm{R}=0.996$.

\subsection{Statistical Analysis of the Results}

All the analytical determinations were performed in triplicates, with estimation of the averages and standard deviations. The DPPH data obtained were submitted to variance analysis and Tukey test ( $<<0.05)$, using the GraphPad PRISM 6 statistic program. To determine the relationship between the total amount of phenolic and the antioxidant activity of the vegetable extracts the correlation coefficient was calculated and a regression analysis was performed using the same statistic program.

\section{Results and Discussion}

The antioxidant activity of the organic vegetables analyzed is presented on Table 1, where it is evidenced that there was no significant difference $(\mathrm{p}<0.05)$ in the consumption percentage of DPPH after 15, 30 and 60 minutes of reaction for all the extracts of the vegetables analyzed.

Among the vegetables analyzed, the effectiveness in the antioxidant capacity was obtained in decreasing order, by the broccoli (69.35), kale (63.20), cabbage (35.72) and carrot (20.39) expressed in \% of consumption of DPPH after 30 minutes of reaction. However, there was no significant difference $(p<0.05)$ between the extracts of organic broccoli and kale in the different reaction times. The broccoli and kale extracts presented a higher efficiency in the free radical scavenging while the cabbage and the carrot showed inhibition percentages lower than $40 \%$, which demonstrates a weak capacity of scavenging DPPH radical.

Melo et al. [29] noticed this differentiated antioxidant capacity among these vegetables. The authors reported that the methanolic extracts of kale, tomato, potatoes, cauliflower, green cabbage, spinach and leaf lettuce, showed inhibition percentages higher than $70 \%$ and were more effective in scavenging the free radicals. The

Table 1. Total phenolic compounds and antioxidant activity (DPPH \% consumed) in organic vegetables extracts.

\begin{tabular}{|c|c|c|c|c|}
\hline \multirow{2}{*}{ Vegetables } & \multirow{2}{*}{ Phenolic totals mg GAE/ml } & \multicolumn{3}{|c|}{ DPPH \% consumed } \\
\hline & & $15 \mathrm{~min}$ & $30 \mathrm{~min}$ & $60 \mathrm{~min}$ \\
\hline Broccoli & $0.511 \pm 0.011$ & $65.69 \pm 4.49^{\mathrm{a}}$ & $69.35 \pm 5.29^{\mathrm{a}}$ & $72.11 \pm 8.26^{\mathrm{a}}$ \\
\hline Cabbage & $0.214 \pm 0.003$ & $33.68 \pm 1.51^{\mathrm{c}}$ & $35.72 \pm 3.39^{c}$ & $37.20 \pm 5.64^{\mathrm{c}}$ \\
\hline Kale & $0.606 \pm 0.014$ & $60.31 \pm 3.25^{\mathrm{ab}}$ & $63.21 \pm 3.85^{\mathrm{ab}}$ & $66.53 \pm 4.49^{\mathrm{ab}}$ \\
\hline Carrot & $0.124 \pm 0.021$ & $19.46 \pm 0.62^{\mathrm{d}}$ & $20.39 \pm 1.13^{\mathrm{d}}$ & $20.92 \pm 1.29^{\mathrm{d}}$ \\
\hline
\end{tabular}

Average \pm three determination standard deviation. Averages followed by the same letter in a column don't differ statistically according to the Tukey test $(\mathrm{p}<0.05)$. 
methanolic extracts of butter lettuce, white onion and string bean showed moderate action (60\% - 70\% inhibition), while the red onion, chayote, cucumber, cabbage and carrot showed the weakest capacity in scavenging the DPPH radical. Similar behavior was observed in this study with the organic vegetables.

In a study presented by Faller and Fialho [1] the antioxidant activity, expressed in radical scavenging capacity (\%RSC) after 60 minutes reacting with the DPPH, was 61.0 for broccoli stalk, 73.8 for broccoli flowers, 79.2 for leafs of organic broccoli, 61.9 for organic carrot peel and 19.0 for organic carrot pulp. These amounts were very similar to the ones found in this study for the organic carrot $(20.92 \% \pm 1.29 \%)$ and organic broccoli $(72.11 \% \pm$ $8.26 \%$ ), after 60 minutes reacting with the DPPH.

The antioxidant action of the bioactive compounds depends on its chemical structure and food concentration, among other factors [29] [30]. The results indicate a possible presence of high antioxidant capacity compounds in the vegetables studied. The bioactive compounds with recognized antioxidant activity present in the carrot are, according to Singh et al. [31], vitamin C, $\beta$-carotene, $\alpha$-carotene, lycopene and lutein, which can vary, among others, according to the cultivation and the nutrient supplementation during the cultivation [31]. Nevertheless, the result of the carrot's antioxidant activity was lower than expected.

The amount of total phenolic compounds found in the organic vegetables studied were: $0.606 \mathrm{mg} \mathrm{GAE} / \mathrm{ml} \mathrm{FE}$ in the kale; $0.511 \mathrm{mg} \mathrm{GAE} / \mathrm{ml} \mathrm{FE}$ in the broccoli; $0.214 \mathrm{mg} \mathrm{GAE} / \mathrm{ml} \mathrm{FE}$ in the cabbage; and $0.124 \mathrm{mg}$ GAE$/ \mathrm{ml}$ FE in the carrot. A positive correlation was observed between the phenolic amounts and the antioxidant activity in the vegetables studied after, 15, 30 and 60 minutes (Figures 1-3).

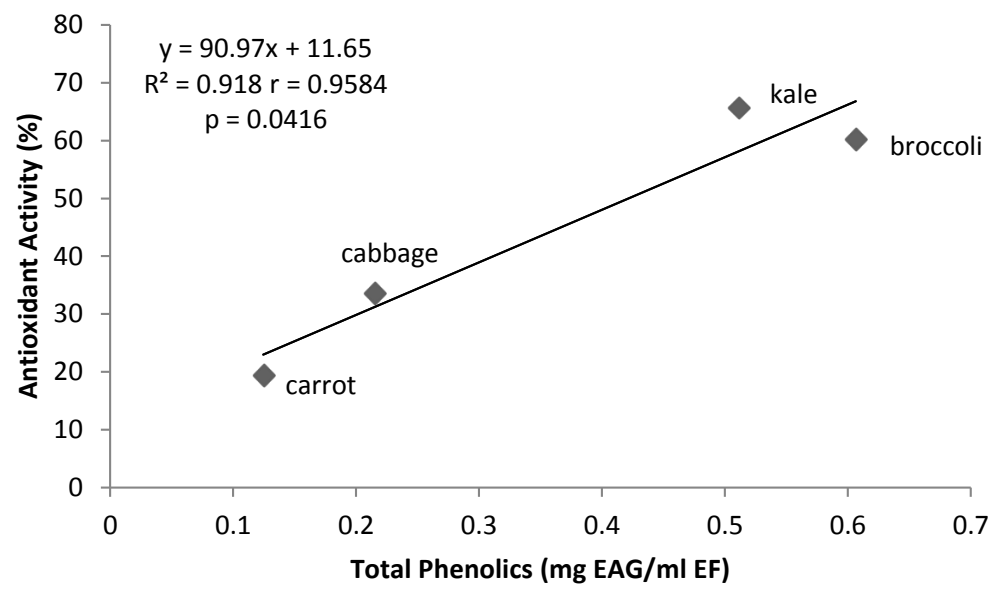

Figure 1. Relationship between the antioxidant activity after 15 minutes and total phenolics of the organic vegetables in the study.

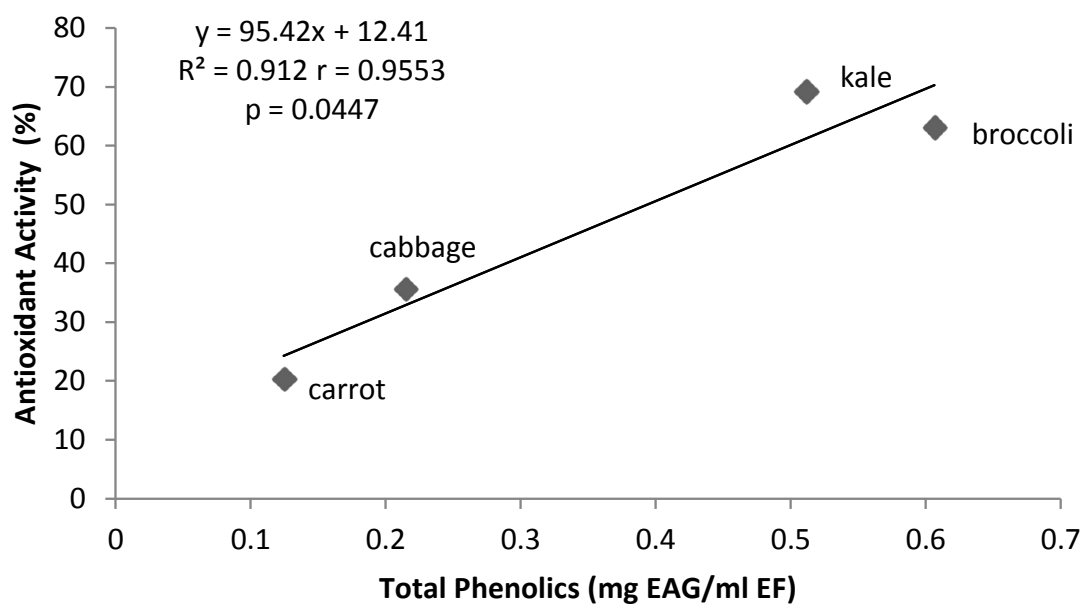

Figure 2. Relationship between the antioxidant activity after 30 minutes and total phenolics of the organic vegetables in the study. 


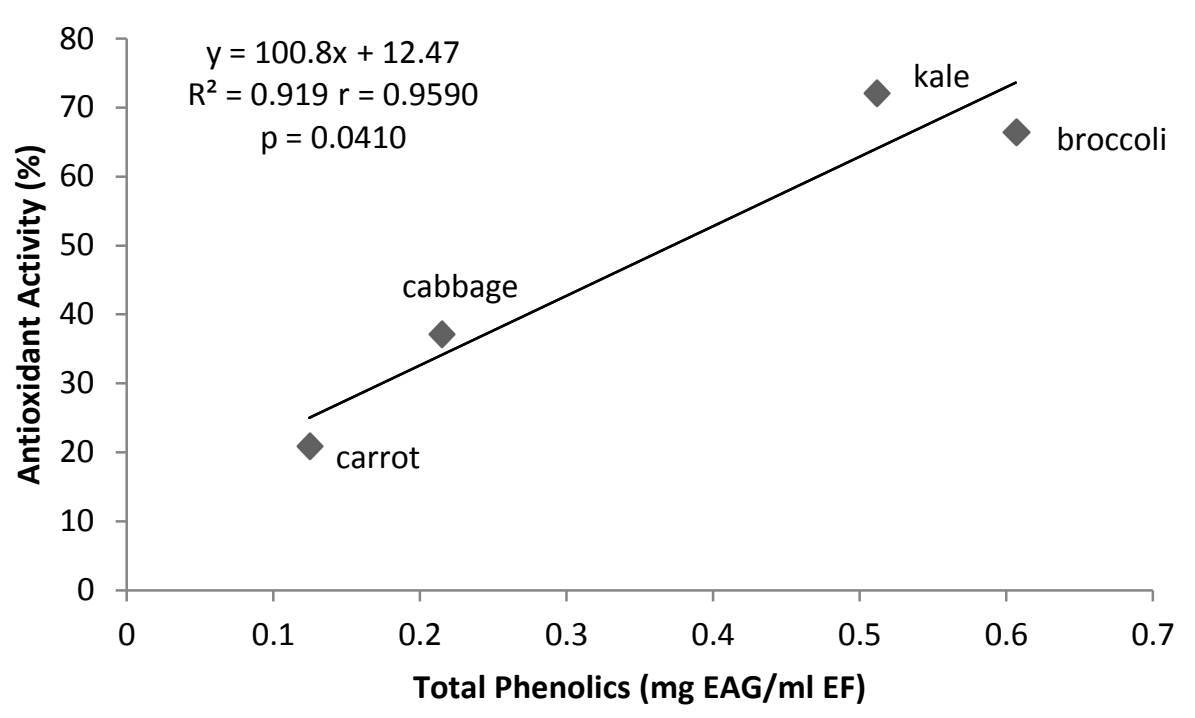

Figure 3. Relationship between the antioxidant activity after 60 minutes and total phenolics of the organic vegetables in the study.

Broccoli, cabbage and kale are vegetables from the Brassicaceae family, better known as crucifers. The protective action of the crucifer vegetables has been associated to the presence of antioxidant vitamins including ascorbic acid, $\alpha$-tocopherol, $\beta$-carotene, however a great part of these vegetables' antioxidant activity comes from phenolic compounds [32].

Singh et al. [33] evaluated the variability of carotenes, vitamin C and E, and phenolic compounds in 5 kinds of Brassica (cabbage, brussels sprout, cauliflower, broccoli and bok choy).

Huber and Rodriguez-Amaya [34] verified that the kale, among the 20 Brazilian vegetables evaluated in his study, showed high amounts of quercetin $(256 \mu \mathrm{g} / \mathrm{g}$ during the winter and $399 \mu \mathrm{g} / \mathrm{g}$ during the summer) and kaempferol (333 $\mu \mathrm{g} / \mathrm{g}$ during the winter and $339 \mu \mathrm{g} / \mathrm{g}$ during the summer). They are phenolic compounds in the flavonoids group with excellent in vitro and in vivo antioxidant potential. In this study, the kale also presented higher amounts of total phenolic compounds and high antioxidant capacity.

\section{Conclusion}

The antioxidant capacity obtained by the DPPH method showed greater expression on the organic broccoli and kale and lower expression on the organic cabbage and carrot; however they all showed a positive correlation with the polyphenols amounts, also greater in kale and broccoli. In view of what was exposed, added to the results obtained, it is possible to assert that the organic vegetables evaluated can contribute to the dietary input of antioxidant compounds. However, phenol profile could be done in the future research because it was not studied in this paper.

\section{Acknowledgements}

The authors are thankful to FAPERJ (Fundação Carlos Chagas Filho de Amparo a Pesquisa do Estado do Rio de Janeiro) for the financial support.

\section{References}

[1] Faller, A.L.K. and Fialho, E. (2009) The Antioxidant Capacity and Polyphenol Content of Organic and Conventional Retail Vegetables after Domestic Cooking. Food Research International, 42, 210-215. http://dx.doi.org/10.1016/j.foodres.2008.10.009

[2] Bianchi, M.L.P. and Antunes, L.M.G. (1999) Radicais livres e os principais antioxidantes da dieta. Revista de Nutrição, Campinas, 12, 123-130. http://dx.doi.org/10.1590/S1415-52731999000200001

[3] Prior, R. L., Wu, X. and Schaich, K. (2005) Standardized Methods for the Determination of Antioxidant Capacity and Phenolics in Foods and Dietary. Journal of Agricultural Food Chemistry, 53, 4290-4302. 
http://dx.doi.org/10.1021/jf0502698

[4] Barreiros, A.L.B.S., David, J.M. and David, J.P. (2006) Estresse oxidativo: relação entre geração de espécies reativas e defesa do organismo. Química Nova, 29, 113-123. http://dx.doi.org/10.1590/S0100-40422006000100021

[5] Catania, A.S., Barros, C.R. and Ferreira, S.R.G. (2009) Vitaminas e minerais com propriedades antioxidantes e risco cardiometabólico: controvérsias e perspectivas. Arquivos Brasileiros de Endocrinologia e Metabologia, 53, 53-55. http://dx.doi.org/10.1590/s0004-27302009000500008

[6] Jáuregui, M.E.C., Carrillo, M.C.C. and Romo, F.P.G. (2011) Carotenoides y su función antioxidante: Revisión. Archivos Latino Americanos de Nutrición, 61, 233-241.

[7] World Health Organization (2004) Resolution WHO 57.17. Global Strategy on Diet, Physical Activity and Health, Proceedings of the $57^{\text {th }}$ World Health Assembly, 22 May 2004, WHO, Geneva.

[8] IBGE (2011) Instituto Brasileiro de Geografia e Estatística. Pesquisa de orçamentos familiares 2008-2009: Análise do consumo alimentar pessoal no Brasil. IBGE, Coordenação de Trabalho e Rendimento, Rio de Janeiro, 150 p.

[9] Brasil (2007) Decreto $n^{\circ}$ 6.323, de 27 de dezembro de 2007. Regulamenta a Lei $n^{\circ} 10.831$, de 23 de dezembro de 2003, que dispõe sobre a agricultura orgânica, e dá outras providências. Diário Oficial da União, Brasília.

[10] Brasil (2003) Ministério da Agricultura. Lei no 10.831, de 23 de dezembro de 2003. Dispõe sobre a agricultura orgânica e dá outras providências. Diário Oficial da União de 24/12/2003, Seção 1, Página 8, Brasília.

[11] Bourn, D. and Prescott, J. (2002) A Comparison of the Nutritional Value, Sensory Qualities, and Food Safety of Organically and Conventionally Produced Foods. Critical Review in Food Science and Nutrition, 42, 1-34. http://dx.doi.org/10.1080/10408690290825439

[12] Mitchell, A.E., Hong, Y.J., Koh, E., Barrett, D.M., Bryant, D.E., Denison, R.F. and Kaffka, S. (2007) Ten-Year Comparison of the Influence of Organic and Conventional Crop Management Practices on the Content of Flavonoids in Tomatoes. Journal of Agricultural and Food Chemistry, 55, 6154-6159. http://dx.doi.org/10.1021/jf070344+

[13] Hoefkens, C., Vandekinderen, I., Meulenaer, B., Devlieghere, F., Baert, K., Sioen, I., Henauw, S., Verbeke, W. and Van Camp, J. (2009) A Literature-Based Comparison of Nutrient and Contaminant Contents between Organic and Conventional Vegetables and Potatoes. British Food Journal, 111, 1078-1097. http://dx.doi.org/10.1108/00070700910992934

[14] Hoefkens, C., Verbeke, W., Aertsens, J., Mondelaers, K. and Van Camp, J. (2009) The Nutritional and Toxicological Value of Organic Vegetables: Consumer Perception versus Scientific Evidence. British Food Journal, 111, 1062-1077. http://dx.doi.org/10.1108/00070700920992916

[15] Dangour, A.D., Dodhia, S.K., Hayter, A., Allen, E., Lock, K. and Uauy, R. (2009) Nutritional Quality of Organic Foods: A Systematic Review. American Journal of Clinical Nutrition, 90, 680-685. http://dx.doi.org/10.3945/ajcn.2009.28041

[16] Dangour, A.D., Dodhia, S.K., Hayter, A., Allen, E., Lock, K. and Uauy, R. (2010) Nutrition-Related Health Effects of Organic Foods: A Systematic Review. American Journal of Clinical Nutrition, 92, 203-210. http://dx.doi.org/10.3945/ajcn.2010.29269

[17] Karakaya, S. (2004) Bioavailability of Phenolic Compounds. Critical Reviews in Food Science and Nutrition, 44, 453464. http://dx.doi.org/10.1080/10408690490886683

[18] Brand-Williams, W., Cuvelier, M.E. and Berset, C. (1995) Use of a Free Radical Method to Evaluate Antioxidant Activity. LWT_Food Science and Technology, 28, 25-30. http://dx.doi.org/10.1016/S0023-6438(95)80008-5

[19] Sánchez-Moreno, C., Larrauri, J.A. and Saura-Calixto, F. (1998) A Procedure to Measure the Antiradical Efficiency of Polyphenols. Journal of the Science of Food and Agriculture, 76, 270-276. http://dx.doi.org/10.1002/(SICI)1097-0010(199802)76:2<270::AID-JSFA945>3.0.CO;2-9

[20] Prior, R.L., Wu, X. and Schaich, K. (2005) Standardized Methods for the Determination of Antioxidant Capacity and Phenolics in Foods and Dietary Supplements. Journal of Agricultural and Food Chemistry, 53, 4290-4302. http://dx.doi.org/10.1021/jf0502698

[21] Sousa, C.M.M., Silva, H.R. and Vieira Jr., G.M. (2007) Fenóis totais e atividade antioxidante de cinco plantas medicinais. Química Nova, 30, 351-355. http://dx.doi.org/10.1590/S0100-40422007000200021

[22] Sharma, O.P. and Bhat, T.K. (2009) DPPH Antioxidant Assay Revisited. Food Chemistry, 113, 1202-1205. http://dx.doi.org/10.1016/j.foodchem.2008.08.008

[23] Mishra, K., Ojha, H. and Chaudhury, N.K. (2012) Estimation of Antiradical Properties of Antioxidants Using DPPH Assay: A Critical Review and Results. Food Chemistry, 130, 1036-1043.

http://dx.doi.org/10.1016/j.foodchem.2011.07.127

[24] Rufino, M.S.M., Alves, R.E., Brito, E.S., Morais, S.M., Sampaio, C.G.S., Pérez-Jiménez, J. and Saura-Calixto, F.D. (2007) Metodologia científica: Determinação da atividade antioxidante total em frutas pela captura do radical livre 
DPPH. Comunicado Técnico 127, EMBRAPA Agroindústria Tropical, Fortaleza, CE July 2007

[25] Swain, T. and Hillis, W.E. (1959) The Phenolic Constituents of Prunus domestica. I.-The Quantitative Analysis of Phenolic Constituents. Journal of the Science of Food and Agriculture, 10, 63-68. http://dx.doi.org/10.1002/jsfa.2740100110

[26] Torres, D.E.G., Mancini, D.A.P., Torres, R.P. and Mancini-Filho, J. (2002) Antioxidant Activity of Macambo (Theobroma bicolor L.) Extracts. European Journal of Lipid Science and Technology, 104, 278-281. http://dx.doi.org/10.1002/1438-9312(200205)104:5<278::AID-EJLT278>3.0.CO;2-K

[27] Quettier-Deleu, C. (2000) Phenolic Compounds and Antioxidant Activities of Buckwheat (Fagopyrum esculentum Moench) Hulls and Flour. Journal of Ethnopharmacology, 72, 35-42. http://dx.doi.org/10.1016/S0378-8741(00)00196-3

[28] Singleton, V.L. and Rossi, J.A. (1965) Colorimetry of Total Phenolics with Phosphomolybdic-Phosphotungstic Acid Reagents. American Journal of Enology and Viticulture, 16, 144-158.

[29] Melo, E.A., Maciel, M.I.S., Lima, V.L.A.G., Leal, F.L.L., Caetano, A.C.S. and Nascimento, R.J. (2006) Capacidade antioxidante de hortaliças usualmente consumidas. Ciência e Tecnologia de Alimentos, 26, 639-644. http://dx.doi.org/10.1590/S0101-20612006000300024

[30] Huber, L.S., Hoffmann-Ribani, R. and Rodriguez-Amaya, D.B. (2009) Quantitative Variation in Brazilian Vegetable Sources of Flavonols and Flavones. Food Chemistry, 113, 1278-1282. http://dx.doi.org/10.1016/j.foodchem.2008.08.030

[31] Singh, D.P., Beloy, J., Mc Inerney, J.K. and Day, L. (2012) Impact of Boron, Calcium and Genetic Factors on Vitamin C, Carotenoids, Phenolic Acids, Anthocyanins and Antioxidant Capacity of Carrots (Daucus carota). Food Chemistry, 132, 1161-1170. http://dx.doi.org/10.1016/j.foodchem.2011.11.045

[32] Singh, J., Upadhyay, A.K., Bahadur, A., Singh, B., Singh, K.P. and Rai, M. (2006) Antioxidant Phytochemicals in Cabbage (Brassica oleracea L. var. capitata). Scientia Horticulturae, 108, 233-237. http://dx.doi.org/10.1016/j.scienta.2006.01.017

[33] Singh, J., Upadhyay, A.K., Prasad, K., Bahadur, A. and Rai, M. (2007) Variability of Carotenes, Vitamin C, E and Phenolics in Brassica Vegetables. Journal of Food Composition and Analysis, 20, 106-112. http://dx.doi.org/10.1016/j.jfca.2006.08.002

[34] Huber, L.S. and Rodriguez-Amaya, D.B. (2008) Flavonóis e flavonas: Fontes brasileiras e fatores que influenciam a composição em alimentos. Alimentos e Nutrição, 19, 97-108. 